\title{
POKLAD KELTSKÝCH MINCÍ OBJAVENÝ V BRATISLAVE \\ ROKU 1776 \\ LOKALIZÁCIA MIESTA NÁLEZU
}

\section{ANDREJ V R T E L - ROBERT GREGOR M A R E T T A}

\begin{abstract}
VRTEL, Andrej - MARETTA, Robert Gregor. A hoard of celtic coins discovered in Bratislava in 1776. Localising the find site. Historický časopis, 2018, 66, 3, pp. 409-428, Bratislava.

The study addresses the localisation of the hoard of Celtic coins discovered on the land of S. Ormosdy in a suburb of Bratislava in 1776. Written reports on the find from the period (J. H. Eckhel, K. G. von Windisch) and their comparison with information on S. Ormosdy's land ownership history in historical-topographic material, church registers, official town books and historical maps are used for the purpose of determining the location. A critical analysis of preserved sources clearly indicates that the hoard was situated in the Blumentál suburb, specifically in the space demarcated by today's Belopotockého, Mýtna, Povraznícka and Žilinská streets. From the perspective of the structure of the Late La Tène settlement agglomeration, the area belonged to the 'satellite settlement' near Námestie slobody (Freedom Square), where three additional hoards of Celtic coins were found in 1927, 1937 and 1942.
\end{abstract}

Key words: Coin hoard discoveries. Bratislava-type Celtic coins. Stephanus Ormosdy. Blumentál suburb. Bratislava oppidum. Satellite settlement. DOI: https://doi.org/10.31577/histcaso.2018.66.3.2

„Ich habe vielleicht nicht nöthig zu errinnern daß es bey Erklärung jener Medaillen, über deren Geburtsort man unschlüssig ist, eine Sache von höchster Wichtigkeit sey, zu wissen, wo sie ausgegraben werden?"

Už krátko po významnom objave hromadného nálezu pri obci Deutsch Jahrendorf (r. 1855) Th. Mommsen upozornil na skutočnost', že t’ažisko výskytu barbarských mincí s nápismi BIATEC, NONNOS a i. ${ }^{1}$ leží v oblasti Bratislavy a Mošo-

1 Názory na súhrnné označovanie skupiny mincí razených v bratislavskom oppide sa v odborných textoch rôznia. Popri prevahe názvov, ktoré odkazujú na charakteristický nápis (mince typu Biatec, biateky: Jan Eisner; mince biatekové skupiny: Vojtech Ondrouch) alebo hlavné 
nu. ${ }^{2} \mathrm{~V}$ druhej polovici 19. storočia ešte neboli splnené podmienky pre utvorenie odôvodnených predstáv o mieste vzniku tzv. biatekov. ${ }^{3}$ Diskusiu v tomto smere podstatnou mierou ovplyvnili mincové depoty, ktoré sa $\mathrm{v}$ Bratislave zaznamenali v r. 1918 - 1945. Postupne sa formujúca generácia bádatel’ov zamerala svoju pozornost' $v$ prvom rade na záchranu a predbežné vyhodnotenie náhodne objavených súborov. ${ }^{4}$ Počet známych hromadných nálezov vzrástol na sedem, ${ }^{5}$ rozsah a skladba numizmatického materiálu sa rozšírili.

Kumulácia vel'kých pokladov mincí typu Biatec priviedla J. Filipa v 50. rokoch $\mathrm{k}$ predpokladu keltského oppida v priestore Bratislavy a tiež k myšlienke, že ich ukrývanie súviselo s nepokojnými, vojnovými udalost'ami. ${ }^{6} \mathrm{~K}$ obdobným záverom dospel na základe analýzy v poradí tzv. šiesteho depotu V. Ondrouch. ${ }^{7}$ Interpretačne prínosné $\mathrm{v}$ jeho monografickej štúdii boli viaceré d’alšie pozorova-

nálezisko (bratislavský typ: Karel Castelin; bratislavské keltské mince: Eva Kolníková), sa pri vol'be pomenovania výnimočne uplatnil neopodstatnený novotvar (mincovníctvo Vel'kobójov: Robert Göbl). K otázkam terminológie pozri: KOLNÍKOVÁ, Eva. Bratislavské keltské mince vo svetle doterajších poznatkov. In Numizmatika, 1998, roč. 16, s. 1. ISBN 8090141404.

2 MOMMSEN, Theodor. Geschichte des römischen Münzwesens. Berlin: Weidmannsche Buchhandlung, 1860, s. 969.

3 Z tohto obdobia pochádza len jeden evidovaný nález mince typu BIATEC na území Bratislavy, z Michalskej ulice: ORTVAY, Theodor. Geschichte der Stadt Preßburg. Erster Band. Von den ältesten Zeiten bis zum Erlöschen des Árpádenhauses. Preßburg: Commissionsverlag von Carl Stampfel, 1892, s. 29, Anm. 2; ORTVAY, Tivadar. Pozsony város utcái és terei. Budapest: Püski Kiadó Kft., 1991, s. 369. ISBN 9637845658. V slovenskom preklade: ORTVAY, Tivadar. Ulice a námestia Bratislavy. Staré Mesto. Bratislava: Albert Marenčin - Vydavatel'stvo PT, 2006, s. 12. ISBN 8089218121; BOROVSZKY, Samu. Magyarország vármegyéi és városai encziklopédiája. Pozsony vármegye. Budapest: Apollo Irodalmi Társaság, 1904, s. 499.

4 Prehl'ad o dejinách archeologického bádania priniesol: POLLA, Belo. Archeológia na Slovensku v minulosti. Martin: Matica slovenská, 1996. ISBN 8070903872. K. Pink v prvom vydaní základnej príručky ku keltskému mincovníctvu poukázal na nedostatočný stav zachovania bratislavských nálezov: ,,Von großen Funden haben wir in der Slowakei drei aus Preßburg, von denen der dritte allein gut erfaßt werden konnte. "PINK, Karl. Einführung in die keltische Münzkunde mit besonderer Berücksichtigung Österreichs. Wien: Franz Deuticke, 1950, s. 24.

5 Zoradené v časovej postupnosti: r. 1920 a pred r. 1930 poloha Hausbergeln; r. 1923 Nám. Slovenského národného povstania (Republiky) - Tatrabanka; r. 1927 a 1937 Nám. slobody; r. 1942 Žilinská (Pöllnská) ul.

6 FILIP, Jan. Keltové ve středni Evropě. Praha: Nakladatelství Československé akademie věd, 1956, s. 239-240; FILIP, Jan. Keltská civilizace a jeji dědictví. Praha: Nakladatelství Československé akademie věd, 1959, s. 116. Porov. tiež: EISNER, Jan. Recenzia Böhm, Jaroslav. Naše nejstarší města. Praha: Společnost čsl. prehistoriků; Prehistorický ústav Karlovy university, 1946. In Památky archeologické, skupina pravěká, 1946, díl XXXXII za rok 1936 -46 , s. 200.

7 ONDROUCH, Vojtech. Keltské mince typu BIATEC z Bratislavy. Poklad velkých strieborných mincí z roku 1942. Bratislava: Vydavatel'stvo Slovenskej akadémie vied, 1958. 
nia a úvahy týkajúce sa štruktúry neskorolaténskeho osídlenia, vzt’ahu k devínskej osade alebo organizácie razby bratislavskej mincovne. ${ }^{8}$

Azda najlepšie sa dá objasnit' názorový posun v otázke bratislavského oppida na príklade Š. Janšáka. Ten v období pred druhou svetovou vojnou vel'mi jednoznačne vyslovil názor, že „u nás neznáme dosial' vôbec ani sídlišta ani hradišt'a, ktoré by podl'a analogie Stradonic a Starého Hradiska pri Plumlove malo tol'ko a takých významných kovových nálezov, patriacich výlučne do laté$n u$ “.9 S odstupom času však už otvorene zvažoval, či miestny sídliskový útvar predstavoval „oppidum s pevnostným systémom “ alebo „,volné sídlisko remeselnikov a kupcov". ${ }^{10}$

Aj napriek dlhodobému záujmu odborníkov o problematiku deponovania mincí v neskorolaténskej Bratislave ${ }^{11}$ sa v staršej i novšej literatúre pri otázke priestorovej distribúcie a kartografického zobrazenia tejto kategórie nálezov opakovane vyskytli niektoré faktografické chyby. Rekonštruovanie pôvodného miesta a spôsobu uloženia nie je jednoduché, pretože takmer všetky depoty mincí bratislavského typu sa vyzdvihli mimo rámca archeologických výskumov a bez stratigrafických pozorovaní. ${ }^{12} \mathrm{~V}$ príspevku sa chceme osobitne venovat' overeniu miesta nálezu prvého mincového depotu, ktorý r. 1776 náhodne objavili na prešporskom predmestí, na roli arcibiskupského správcu Štefana Ormosdyho $(1741-1795) .{ }^{13}$

8 KOLNÍKOVÁ, Eva. Náčrt problematiky keltského mincovníctva na Slovensku. In Slovenská numizmatika, 1984, roč. VIII, s. 29. ISSN 0081-0088.

9 JANŠÁK, Štefan. Staré osídlenie Slovenska. Turčiansky sv. Martin: Matica slovenská, 1938, S. 114.

10 JANŠÁK, Štefan. Hrnčiarska dielňa z neskorého laténu v Bratislave. In Slovenská archeológia, 1955, roč. III, s. 218. ISSN 1335-0102.

11 Z novších príspevkov napr.: ČAMBAL, Radoslav - BUDAJ, Marek. Keltské tetradrachmy z Pezinka a Bratislavy-Rače. In Zbornik Slovenského národného múzea, 2009, roč. CIII, Archeológia 19, s. 197-214. ISBN 9788080602444; MILITKÝ, Jiří. Hromadný nález hexadrachem typu Biatec z neznámé lokality a nový typ bratislavské mince s nápisem LATTV. In Numismatický sborník, 2013, roč. 27, č. 2, s. 161-178. ISBN 9788070074084; MILITKÝ, Jiří. Hromadný nález hexadrachem typu Biatec a stř́brného ingotu z neznámé lokality. K otázce původu stříbra u středoevropských Keltů. In Numismatické listy, 2013, roč. 68, č. 3-4, s. 99122. ISSN 0029-6074; MILITKÝ, Jiří. Ein neuer Hexadrachmentyp vom Typ Biatec mit der Aufschrift LATTV. In Mitteilungen der Österreichischen Numismatischen Gesellschaft, 2014, Band 54, Nr. 1, s. 25-38. ISSN 0029-9359.

12 Na túto okolnost' poukázal už napr.: REXA, Daniel. K lokalizácii mincovnej dielne na území Bratislavy v dobe laténskej. In Najstaršie dejiny Bratislavy. Referáty zo sympózia 28.- 30. októbra 1986. Zost. Vladimír Horváth. Bratislava: Bratislavská informačná a propagačná služba; Archív hlavného mesta SSR Bratislavy, 1987, s. 64.

13 V staršej literatúre sa stretávame i s nepravdivým údajom o čase nálezu r. 1775, porov.: PETRIKOVICH, Ján. Mince keltické v Uhorsku. In Sbornik Muzeálnej slovenskej spoločnosti, 
Z oboznámenia sa so spisbou z prvej polovice 20. storočia jasne vyplýva, že prevažná väčšina autorov ostala pri konštatovaní neznámej alebo bližšie neurčenej polohy náleziska. ${ }^{14}$ Rovnaké závery obsahujú i moderné prehl'adové state a heslá v topografických dielach. ${ }^{15}$

Eva Kolníková vo svojich prácach bez podrobnejšieho odôvodnenia uviedla, že miesto nálezu leží „,mimo areálu oppida na pravom brehu Dunaja “ alebo ,,za Dunajom " ${ }^{16}$ Jej tvrdenie sa pravdepodobne zakladá na správe J. G. Seidla z roku 1856 o hromadnom náleze keltských mincí pri obci Deutsch-Jarendorf v Mošonskej stolici (Wieselburger Comitat; Kreis jenseits der Donau). ${ }^{17}$ Seidl tu v závere krátkeho exkurzu poznamenal, že poklad z r. 1776 sa našiel na tom istom území (,, in derselben Gegend"). Vyjadrenie autora je však neurčité a k tomu nepredstavuje priamy, historicky hodnoverný doklad súčasníka objavu. ${ }^{18}$

Odlišný názor nedávno vyslovila $\mathrm{M}$. Pichlerová, ktorá - s odvolaním sa na Marquartov plán Bratislavy z r. 1765 - označila za miesto nálezu pozemok „, v blizkosti Primacionálneho námestia “. ${ }^{19}$ Tento pokus o lokalizáciu však mož-

1903, roč. VIII, zv. II, s. 95.

14 FORRER, Robert. Keltische Numismatik der Rhein- und Donaulande. Strassburg: Verlag von Karl J. Trübner, 1908, s. 128; GOHL, Ödön. A rétei barbár ezüszpénz-lelet. In Numizmatikai Közlöny, 1909, VIII, s. 1; DESSEWFFY, Miklós. A „BIATEC“ feliratú 17 grammos barbár ezüstpénzek bélyegváltozásai. In Archceologiai értesitő, 1916, roč. XXXVI, s. 54. „,Nalezen ve městě “: EISNER, Jan. Bratislava v době pravěké a raně dějinné. In Ročenka vedeckých ústavov mesta Bratislavy na rok 1934. Ed. Ovidius Faust. Bratislava: Mestské vedecké ústavy, 1934, s. 72; ONDROUCH, Vojtech. Limes Romanus na Slovensku. Bratislava: Učená společnost Šafaříkova v Bratislavě, 1938, s. 75; ONDROUCH, Vojtech. Nálezy keltských, antických a byzantských mincí na Slovensku. Bratislava: Vydavatel'stvo Slovenskej akadémie vied, 1964, s. 61; PINK, Karl. Die Münzprägung der Ostkelten und ihrer Nachbarn. Budapest: Institut für Münzkunde und Archäologie der P. Pázmány-Universität, 1939, s. 143.

15 POLLA, Belo - VALLAŠEK, Adrian. Archeologická topografia Bratislavy. Bratislava: Veda, 1991, s. 180. ISBN 8022402508.

16 MUSILOVÁ, Margaréta - KOLNÍKOVÁ, Eva - HLOŽEK, Martin. „Rímska stavba I“ na akropole bratislavského keltského oppida - svedectvo mincí. In Slovenská archeológia, 2015, roč. LXIII, č. 2, s. 267. ISSN 1335-0102; KOLNÍKOVÁ, Eva. Bratislavské keltské mince. Bratislava: Tatran, 1991, s. 24. ISBN 8022202819; KOLNÍKOVÁ, Eva. Mince - svedectvo prosperity Keltov. In Dejiny Bratislavy 1. Od počiatkov do prelomu 12. a 13. storočia. Brezalauspurc na križovatke kultúr. Zost. Juraj Šedivý, Tatiana Štefanovičová. Bratislava: Slovart, 2012, s. 215. ISBN 9788055603308.

17 SEIDL, Johann Gabriel. Beiträge zu einer Chronik der archaeologischen Funde in der österreichischen Monarchie. In Archiv für Kunde österreichischer Geschichts-Quellen. Band XV. Wien: K.-k. Hof- und Staatsdruckerei, 1856, s. 302-305.

18 Johann Gabriel Seidl sa r. 1840 stal kustódom Cisárskeho kabinetu mincí a starožitností vo Viedni.

19 PICHLEROVÁ, Magdaléna. Odkrývanie najstarších dejín Bratislavy. Výskumy, inštitúcie a bádatelia. In Dejiny Bratislavy 1. Od počiatkov do prelomu 12. a 13. storočia. Brezalauspurc na križovatke kultúr. Zost. Juraj Šedivý, Tatiana Štefanovičová. Bratislava: Slovart, 2012, 
no vyvrátit' jednoznačným konštatovaním, že legenda na pláne s registrom majitel'ov domových parciel vo vnútornom meste (Explicatio in der Stadt) meno Štefana Ormosdyho neuvádza. ${ }^{20}$ Ormosdy v skutočnosti kúpil objekt bývalého jezuitského kolégia na Primaciálnom námestí až r. 1777. ${ }^{21}$ Dalšia výhrada spočíva $\mathrm{v}$ tom, že umiestenie do historického jadra nezodpovedá žiadnemu z dobových opisov polohy.

Týmito protichodnými hypotézami sa vyčerpáva výpočet doterajších pohl'adov na konkrétne situovanie miesta nálezu. V numizmatickej a archeologickej literatúre sa bádatelia $\mathrm{k}$ týmto názorom už viac nevyjadrili. $\mathrm{Z}$ krátkeho náčrtu dejín bádania je navyše zrejmé, že pri objasňovaní topografie náleziska sa v slovenskej odbornej spisbe doposial' neuplatnil prístup založený na komparácii pôvodných správ o nálezových okolnostiach a rozsiahleho archívneho materiálu, ktorý zahŕňa historické topografie, mestské úradné knihy, cirkevné matriky, kartografické pamiatky a d'alšie pramene.

\section{Historické správy o náleze}

Ako vôbec prvý priniesol správu o objave mincí J. H. Eckhel, vtedajší riaditel' cisárskej numizmatickej zbierky a zároveň profesor ,,starožitností a pomocných vied historických" na viedenskej univerzite. Abbé Eckhel v dvojdielnom príspevku uverejnenom začiatkom apríla r. 1777 v týždenníku Kaiserlich königliche allergnädigst privilegirte neue Realzeitung opísal miesto a okolnosti nálezu týmito slovami:

„Im verflossenen Jahre fand ein Taglöhner beym Umgraben der Erde ein kleines irdenes Geschirr worinn sich 5 alte Silbermünzen befanden. Diese Entdeckung geschah zu Ormosd einem im Pressburgerkomitat gelegenen Flecken, und man bezeuget hier der $k$. $k$. Hofkamer alle Verbindlichkeit, der er beliebet hat, diese Ueberbleibsel des Alterthums zu retten, und sie unverstreut in das $k$. Medaillen-kabinet zu liefern. "22

V d'alších riadkoch Eckhel vyzdvihol kvalitu mincového kovu (,,im feinstem Silber") a vysokú hmotnost' týchto piatich barbarských razieb (,,ungefähr 4

s. 523. ISBN 9788055603308.

20 Originál mapy Archív mesta Bratislavy (d’alej AMB), fond (d’alej f.) Zbierka máp a plánov, inv. č. 656; faksimilné vydanie: Bratislava, mapa z roku 1765 (autor sprievodného textu Hedviga Hudáková). Bratislava: Slovenská kartografia, 1988.

21 Rozhodnutie pápeža Klementa XIV. o zrušení Spoločnosti Ježišovej bolo vyhlásené 3. septembra 1773 král'ovským dekrétom Abolitionis Societatis Jesu decretum aulicum. Bližšie v práci: ŠPIRKO, Jozef. Cirkevné dejiny s osobitným zretel’om na vývin cirkevných dejín Slovenska. Sväzok II. Turčiansky Sv. Martin: Neografia, 1943. s. 295-297, 308.

22 ECKHEL, Joseph Hilarius. Entdeckung antiquarischen Inhalts. In Kaiserl. königl. aller. privil. neue Realzeitung. Wien 1777, Erstes Stück, Den 1ten April, s. 8. 
Drachmen"). Pomerne obšírne sa zamýšlal nad pôvodom a predlohami mincí $\mathrm{s}$ nápismi BIATEC, ${ }^{23}$ FAPIAI $\Omega$ (FAPIARIX) ${ }^{24}$ a spomenul známe analógie uložené v zbierkach J. Pellerina ${ }^{25}$ a benediktínskeho kláštora Gottwich (Göttweig). Na záver svojej správy podotkol, že ich časové postavenie výraznejšie nepredchádza r. 50 pred $\mathrm{Kr}^{26}$

V máji toho roku vyšiel vo Wiener Realzeitung príspevok z pera K. G. Windischa, ktorý vzniesol kritické námietky proti mylnému umiestneniu nálezu a doslovne napísal: „, Da aber die Nachricht, wie diese Münzen gefunden worden, unrichtig ist, so erweise ich dem würdigem Verfasser dieser Untersuchung ohne Zweifel einen Dienst, wenn ich, als ein Augenzeuge, dieselbe hiemit berichtige. [...] Den 5ten July 1776. fanden die Arbeiter, welche Kieserde zur Ausschüttung der Landstrassen, auf einem dem erzbischöflichen Hofrichter Herrn v. Ormoschdy zugehörigen Acker in der äusserssten Prespurger Vorstadt gruben, einen irdenen Napf, und in demselben vier und vierzig $S(t) \ddot{u} c k e$ Silbermünzen, von verschiedenen Gepräge... "27

Z hladiska vierohodnosti niet dôvodu svedectvo K. G. Windischa spochybňovat', pretože prešporský vydavatel' a vzdelanec, vedecky činný v oblasti geografie, bol bezprostredne znalý miestnych pomerov. ${ }^{28} \mathrm{Z}$ jeho formulácie vyplývajú pre lokalizovanie miesta hromadného nálezu tieto konkrétne oporné body:

23 ECKHEL, Entdeckung, ref. 22, s. 11.

24 ECKHEL, Joseph Hilarius. Beschluß der Entdeckung antiquarischen Inhalts. In Kaiserl. königl. allerg. privil. neue Realzeitung. Zweytes Stück, Den 8ten April, Wien 1777, s. 18. K rôznym výkladom nápisu pozri: COLBERT DE BEAULIEU, Jean-Baptiste. Nápis FARIARIX má být správně čten PLARIARIX. In Numismatické listy, 1961, roč. XVI, s. 147. ISSN 0029-6074; RÖTTGER, Christoph. DEVII, FAPIARIX und FAPIARIX retrograd. Vorschlag zur korrekten Lesung einiger Münzlegenden. In Numismatický sbornik, 2012 - 2013, roč. 27 , č. 1, s. 27-33. ISBN 9788070074077.

25 Zaradené medzi tzv. bližšie neurčené razby (médailles incertaines): „Il y a toute apparence que ces six médailles, dont les cinq premières sont de petits médaillons d'argent fort épais, présentent des chefs de peuples particuliers, qui s'étant soumis aux Romains \& alliés avec eux, auront, à leur exemple, fait frapper des médailles avec leurs noms, qui ne nous ont point été transmis par les Historiens. "Pozri: PELLERIN, Joseph. Recueil de médailles de peuples et de villes, qui n'ont point encore été publiées ou qui sont peu connues. Tome premier; Contenant les Médailles d'Europe. Paris: H. L. Guerin \& L. F. Delatour, 1763, s. 11, Pl. II: nº 25. Reprodukcie obrazov mincí s legendou BIATEC (variant s motívom dvoch hláv rímskych cností Honos a Virtus na lícnej strane) a SONNON zachované už v spise: WILDE, Jacob de. Selecta numismata antiqua. Amstelodami, 1692, s. 91-92, tab. XI: 63, 64.

26 ECKHEL, Beschluß, ref. 24, s. 20.

27 WINDISCH, Karl Gottlieb. Alterthümer. In Kaiserl. Königl. aller. Privil. neue Realzeitung. Wien 6. St., 6. Mai, 1777, s. 92-93.

28 Windisch bol postupne zvolený za člena mestskej rady (r. 1768), mestského kapitána (r. 1774, 1778) a mešt'anostu Prešporka (r. 1789): VALJAVEC, Fritz. Karl Gottlieb Windisch. Das Lebensbild eines südostdeutschen Bürgers der Aufklärungszeit. München: Verlag Max Schick, 
1. poloha vo vonkajšom predmestí;

2. rol'a vo vlastníctve von Ormosdyho;

3. blízkost' Krajinskej cesty.

Bez toho, aby sme na tomto mieste hlbšie rozoberali obsahovú stránku depotu z r. 1776, aspoň v krátkosti upozorníme na niektoré skutočnosti uvedené vo Windischovej odpovedi. Podl'a opisu vážili mince 1 lót $(17,5 \mathrm{~g})$ a vyznačovali sa striebrom rýdzosti 14 lótov $(875 / 1000) .{ }^{29} \mathrm{~V}$ súbore 44 razieb sa vyskytovali tri rôzne varianty s nápisom BIATEC, mince s nápismi ZONNOH (SONNON), NONNOS, COBLIOW (COBROVOMARUS) a jeden typ s vyobrazením harpye a nečitatel’ným nápisom na rube. ${ }^{30}$

Poklad sa roztratil po verejných a súkromných zbierkach. F. A. Pulszky s odstupom času poznamenal, že čast’ nálezu prevzal Kabinet starožitností vo Viedni a d'alšiu Mad'arské národné múzeum v Budapešti. ${ }^{31} \mathrm{R}$. Paulsen vo svojom katalógu evidoval len jednu mincu typu BIATEC s uvedením pôvodu „,aus dem Schatzfunde vom Pressburg vom Jahre 1776 “. ${ }^{32}$ Príslušnost' ostatných exemplárov k nálezisku je neistá. ${ }^{33}$

\section{Lokalizácia miesta nálezu na základe analýzy písomných prameňov}

Termín „äußersste Vorstadt“ odkazuje na tzv. vonkajšie predmestie, ktoré vyrástlo za druhým prstencom opevnenia, na mieste bývalých polí, záhrad a vinohradov. Prvé objekty vybudovali na terajšej Vazovovej ul. (Neubau) už roku $1702 .{ }^{34}$ Najstaršie pomenovanie tejto predmestskej lokality - Blumenthal (Kvetná dolina) - sa uvádza r. 1729 v súvislosti s rozpredajom pozemkov. ${ }^{35}$ Stavebný rozvoj novej štvrte výstižne zaznamenal M. Bel vo svojich Notíciách ${ }^{36}$ Hlavné

\section{6, s. 16.}

29 WINDISCH, ref. 27, s. 94. Prevod z dolnorakúskej sústavy mier a váh podl’a: NOVÝ, Rostislav. Historická metrologie. In Vademecum pomocných věd historických. Praha: Svoboda, 1988, tab. IV.

30 WINDISCH, ref. 27, s. 93-94. Nepravdivý údaj „,mince bez nápisu“: ONDROUCH, Limes Romanus, ref. 14, s. 75.

31 PULSZKY, François von. Monuments de la domination celtique en Hongrie. In Revue archéologique, Nouvelle série, 1879, XXXVIII, s. 170. Porov.: POLLA, ref. 4, s. 223.

32 PAULSEN, Rudolf. Die Münzprägungen der Boier. Leipzig: Verlag Heinrich Keller; Wien: Anton Schroll \& Co., 1933, s. 103, 157, Taf. 32: 751.

33 PAULSEN, ref. 32, s. 156, Inv. Nr. 26741, Taf. 31: 746; DESSEWFFY, Miklós. Barbár pénzei. Budapest: Hornyánsky Viktor cs. és kir. udvari könyvnyomdája, 1910.

34 HORVÁTH, Vladimír. Bratislavský topografický lexikon. Bratislava: Tatran, 1990, s. 30, 306. ISBN 8022202290.

35 HORVÁTH, ref. 34, s. 30, 163.

36 BEL, Matthias. Notitia Hungariae novae historico-geographica, I, II. Viennae, 1735 - 1736, VI. kap., I. zv., II, § 14. Komentovaný preklad vybraných kapitol: Bratislava Mateja Bela. Bratislava: Obzor, 1984, s. 122. 
osi osídlenia vopred určili výpadové cesty z mesta. Roku 1769 žilo na blumentálskom predmestí, od Hlbokej cesty po Mlynské nivy, v 457 domoch 7835 l'udí. ${ }^{37}$ Pre rýchlo sa rozrastajúcu štvrt' preto zriadili r. 1770 samostatnú farnost'. ${ }^{38}$

V r. 1775 - 1778 sa začala uskutočňovat' vel'ká regulácia mesta podl'a projektu architekta F. A. Hillebrandta. Zbúraním hradieb a zasypaním priekop sa mesto postupne zlúčilo s predmestiami do jedného celku. ${ }^{39}$ Napriek tomu J. M. Korabinský pri opise topografických pomerov v Prešporku aj nad’alej členil priestor na vnútorné mesto a predmestia. ${ }^{40}$ Pritom treba upozornit', že u Korabinského názov Blumenthal označoval užšie vymedzenú oblast' Záhradníckej ulice. ${ }^{41}$

Štefan Ormosdy pochádzal z Pešti, pokrstený bol 25. decembra 1741 vo farnosti Belváros. ${ }^{42}$ Usadil sa $\mathrm{v}$ Bratislave, z dobových dokumentov vyplýva, že mešt'anom sa stal r. 1771 (Stephanus Ormosdy oeconomus) ${ }^{43}$ Už od r. 1764 zastával úrad hospodárskeho správcu arcibiskupských majetkov (provízor, vedúci úradník panstva). ${ }^{44}$ Roku 1782 získal od cisára Jozefa II. šl’achtictvo, erb a majetok Padej v Torontálskej stolici. ${ }^{45} \mathrm{~S}$ manželkou Teréziou rodenou Seiffovou mali 11 detí. Zomrel 3. februára 1795 v Podunajských Biskupiciach. ${ }^{46}$

Písomné pramene umožňujú vcelku spol’ahlivo sledovat' základný vývoj Ormosdyho majetkových pomerov v sedemdesiatych rokoch 18. storočia. Cenný miestopisný prameň predstavuje najmä Opis královského uhorského hlavného

37 HORVÁTH, ref. 34, s. 163; ŠPIESZ, Anton. Bratislava v 18. storočí. Bratislava: Tatran, 1987, s. 29.

38 BAGIN, Anton - KRAJČI, Jozef. Kostoly a kaplnky hlavného mesta SSR Bratislavy. Bratislava: Cirkevné nakladatel'stvo, 1988, s. 35, 127. Ďalšie konkrétne údaje k historickému miestopisu pozri: OBUCHOVÁ, Viera. Príbehy z dejín Bratislavy. Bratislava: Albert Marenčin - Vydavatel'stvo PT, 2013. ISBN 9788081143120; OBUCHOVÁ, Viera. Topografia Blumentálu v zrkadle archívnych prameňov. In Pamiatky a múzeá. Revue pre kultúrne dedičstvo, 1999, č. 1, s. 21-25. ISSN 1335-4353.

39 ŠEVČÍKOVÁ, Zuzana. Mestské opevnenie Bratislavy. Bratislava: Obzor, 1974, s. 30-31.

40 „Die Gassen der dermaligen Vorstädte“: KORABINSKY, Johann Mathias. Beschreibung der königl. ungarischen Haupt-, Frey- und Krönungstadt Preßburg. Erster Theil. Preßburg, 1781, s. 85. Názov „Vnútorné mesto “ sa používal až do r. 1880.

41 Pozri v legende územie pod č. 34: AMB, f. Zbierka máp a plánov, inv. č. 31/620. „Im Blumenthal: die Holler- und Felbergasse": KORABINSKY, Johann Matthias. Geographisch-historisches und Produkten Lexikon von Ungarn. Preßburg, 1786, s. 562.

42 Meno sa v úradných písomnostiach vyskytuje vo formách Ormosdy, Ormoschdy.

43 AMB, f. Magistrát mesta Bratislavy, Poplatky za prijatie za mešt’ana z r. 1754 - 1791, sign. 2e4, s. 164.

44 Podl'a staršej literatúry od r. 1760: PÜSPÖKI NAGY, Peter. Podunajské Biskupice. Monografia staršich dejín. Bratislava: Dom osvety, 1969, s. 153.

45 Magyar Nemzeti Levéltár Országos Leveltára, Libri Regi II, num. s. 177.

46 PÜSPÖKI NAGY, ref. 44, s. 152. 
slobodného a korunovačného mesta Prešporku s nákresom mesta a jeho okolia od J. M. Korabinského. ${ }^{47} \mathrm{~V}$ spise, ktorý ozrejmuje historické priestorové vzt'ahy a vlastníctvo objektov, sa Ormosdyho meno spomína pri výpočte parciel na predmestí s poznámkou ,Herr Stephan Ormoschdy ein doppeltes Eck in die mittlere und untere Hauergasse nebst Garten und Acker. "48 Tieto údaje prebral T. Ortvay: „Na jej mieste [c. k. kadetskej školy - A. V., R. G. M.] stál za čias Korabinského dom Štefana Ormósdyho (neskôr Koditzkého), ktorýtvoril roh dvoch ulic - Strednej a Dolnej Kopáčskej. Mal ornú pôdu a záhradu s celkovou rozlohou 12783 štvorcových siah. " "49 V Korabinského ponímaní patrila Kopáčska ulica do štvrte pred Suchomýtnou bránou (,,vor dem Dürrenmautthor "). ${ }^{50}$ Jej pomenovanie sa odvodzuje od povolania kopáčov, využívaných nielen na prácu vo vinohradoch, ale aj pri híbení a údržbe priekop alebo podobných mestských objektov. ${ }^{51}$ Treba ešte raz osobitne podotknút, že súčast'ou tohto rozsiahleho majetku na Mýtnej ulici bola i rol'a.

Ďalšie podporné údaje na overenie vtedajšieho bydliska S. Ormosdyho sprostredkúvajú cirkevné matriky. Podl'a záznamov uzavrel sobáš s Teréziou Seiffovou 7. septembra 1775 v bratislavskej farnosti Blumentál. ${ }^{52} \mathrm{Krst}$ ich prvorodenej dcéry Terézie Barbary Eleonóry 7. júna 1776 sa tak isto uskutočnil v blumentálskej fare na predmestí. ${ }^{53} \mathrm{~V}$ poradí druhú dcéru pokrstili ako Eleonóru Máriu 29. júla 1778 v Dóme sv. Martina a stručná poznámka v evidencii krstov uvádza, že primaciálny provízor býval $\mathrm{v}$ tom čase mimo mesta (, extra civitatem ")..$^{54}$

Na sever od Palisád, ned’aleko cesty vedúcej k Tomášovej studni (Tieffer Weg zum Thomas-Brünn) vlastnil vinohrad (Herrn Stephan v Ormosdy Weingarten). Polohu vinice zachytáva podrobný nákres s názvom Geometrischer Entwurf des

47 Spôsob spracovania topografie podrobil kritike nemecký cestovatel' Friedrich Nicolai (1733 - 1811): TANCER, Jozef. Neviditel'né mesto. Prešporok/Bratislava v cestopisnej literatúre. Bratislava: Kalligram, 2013, s. 38-39. ISBN 9788081016653.

48 KORABINSKY, Beschreibung, ref. 40, s. 89.

49 Citované podl'a slovenského vydania: ORTVAY, Tivadar. Ulice a námestia Bratislavy. Nové Mesto. Bratislava: Albert Marenčin - Vydavatel'stvo PT, 2007, s. 94. ISBN 9788089218547. Výmera pozemku v prepočte takmer 460 árov.

50 KORABINSKY, Geographisch-historisches, ref. 41, s. 561-562.

51 ORTVAY, Nové Mesto, ref. 49, s. 94; HORVÁTH, ref. 34, s. 30, 57.

52 AMB, f. Zbierka cirkevných matrík, Matrika sobášených farnosti Bratislava-Blumentál z r. $1770-1779$, s. 63.

53 AMB, f. Zbierka cirkevných matrík, Matrika pokrstených farnosti Bratislava-Blumentál z r. $1770-1783$, s. 172.

54 AMB, f. Zbierka cirkevných matrík, Matrika pokrstených farnosti Bratislava-Sv. Martin z r. 1776 - 1779, s. 388. 
Bestimmten Weingarten zum Evangelischen Freydhoff von den Gayss-Thor, nebst Umliegender Gegend z r. $1783 .{ }^{55}$

Vo vnútornom meste Ormosdy kúpil r. 1777 objekt pôvodného kolégia rádu jezuitov na Primaciálnom námestí a dal ho prestavat' na obytný palác. ${ }^{56} \mathrm{~V}$ paláci sa potom nezdržiaval, upravené priestory prenajímal - v Korabinského topografii je budova uvedená ako ,, das Ormoschdische Hotel “ ${ }^{57}$ Nachádzala sa tu prepychovo zariadená kaviareň, označená v správe z r. 1783 za vôbec najkrajšiu v celom Uhorsku. ${ }^{58}$

Štefan Ormosdy okrem uvedených bratislavských sídel nadobudol časom značné nehnutel'nosti a pozemkové majetky v chotári Podunajských Biskupíc (Bischdorf, Pischdorff). Arcibiskup Jozef Batthyáni ho za verné služby odmenil r. 1779 Botossyho a r. 1787 Weisenthalovou kúriou. ${ }^{59}$ V r. 1779 - 1786 si tu Ormosdy nechal vybudovat' nový kaštiel'. ${ }^{60}$ Proti stotožneniu miesta nálezu z roku $1776 \mathrm{~s}$ týmito Ormosdyovskými pozemkami hovorí v prvom rade skutočnost', že Biskupice mali od 16. storočia právne postavenie samostatného mestečka (oppidum). ${ }^{61}$

Windischova zmienka o ,krajinskej ceste“ sa vzt'ahuje najskôr na priebeh dnešnej Radlinského ulice. Všeobecné označenie Landstrasse/Ország út niesli síce všetky dôležité výpadové komunikácie smerujúce von z mesta, ${ }^{62}$ no poloha, na ktorej robotníci t’ažili drobný štrk na vysypanie vozovky, asi nemohla byt' d’aleko od upravovaného úseku - prevážat' l'ahko dostupný materiál na väčšie vzdialenosti by predstavovalo iba zbytočné náklady. V 70. rokoch 18. storočia sa cesta vo vonkajšom predmestí od Schöndorfskej brány k Račianskemu mýtu nazývala Ober/Obere Landstrasse alebo Aussern Linie-Gassen in Poindl. ${ }^{63} \mathrm{Z}$ vo-

55 Magyar Nemzeti Levéltár Országos Levéltára, Térképtár, f. S 12 Helytartótanácsi térképek, sign. Div. XVI. - No. 52:1.

56 ORTVAY, Staré Mesto, ref. 3, s. 185; HOLÁK, Ján. Topografia historického jadra Bratislavy v 18. storočí. In Bratislava, ročenka, zv. 3, 1967, s. 153; MENCL, Václav - MENCLOVÁ, Dobroslava. Bratislava, stavebni obraz města a hradu. Praha: Jan Štenc, 1936, s. 126; WAGNER, Vladimír. Vývin palácového stavitel'stva Bratislavy v XVIII. storočí. In Ročenka vedeckých ústavov mesta Bratislavy na rok 1934. Ed. Ovidius Faust. Bratislava: Mestské vedecké ústavy, 1934, s. 376.

57 KORABINSKY, Beschreibung, ref. 40, s. 40.

58 CMOREJ, Július. Bratislava - svedectvo historických pohladnic. Poprad: Region Poprad, 2004, s. 48-49. ISBN 809691006; HOLČÍK, Štefan. Spomienkový album. In Bratislavské noviny, 1999, roč. 2, č. 19 (7. 10. 1999). ISSN 1335-5228.

59 PÜSPÖKI NAGY, ref. 44, s. 153.

60 Budova kaštiel’a bola zbúraná začiatkom 50. rokov 20. storočia.

61 KOL. Súpis pamiatok na Slovensku, zväzok druhý, $K-P$. Bratislava: Slovenský ústav pamiatkovej starostlivosti a ochrany prírody; Obzor, 1968, s. 493-494.

62 HORVÁTH, ref. 34, s. 17, 245.

63 HORVÁTH, ref. 34, s. 245. 
jenských opisov jozefínskeho mapovania sa vie, že i hradská vedúca d’alej na Raču mala dobre udržiavaný, pevný, vydláždený povrch. ${ }^{64}$

\section{Polohové určenie na historických mestských mapách a plánoch}

$Z$ časového rozpätia druhej polovice 18 . storočia sa zachoval pomerne početný súbor máp a plánov Bratislavy ${ }^{65}$ Niektoré z týchto mapových diel výstižne zaznamenávajú stavebný vývin predmestí, ich polohopis a výnimočne i odkazy na majitel'ov jednotlivých domových parciel.

Rukopisná mapa Grundrisz der königlichen freyen krönungs Stadt Preszburg nebst der umliegendem Gegend ${ }^{66}$ ktorú r. 1781 zhotovil J. M. Korabinský ako prílohu k historicko-prírodovednej topografii, znázorňuje na predmestí väčšinou len obrysy celých zastavaných uličných blokov. ${ }^{67}$ Vo vysvetlivkách je o. i. uvedené pomenovanie piatich vel'kých palácových záhrad (Garten: Pálfische; Erdödische; Grasalkovicz; Fürst Primas; Aspermont) ${ }^{68}$

Pre našu tému je osobitne cenný čiastkový plán Pozsony a Récsei és Vallon utca környéki részének helyszínrajza z r. $1777 .{ }^{69}$ Plán v podrobnej mierke obsahuje zobrazenie rázcestia ulíc Mýtna (Strasse gegen Ratzstorff), Slovanská (Waloner Gassen) a Vazovova (miesto názvu poznámka Gassen 13. Klaffter breits). ${ }^{70}$ Ako výrazný orientačný prvok pri skúmaní topografie tu vystupuje aj Pálffyovský majer (Graf. Joh. Palffisser Maÿrhoff). ${ }^{71}$ Na Mýtnej ulici, naproti

64 KLEIN, Bohuš. Významné mestá Slovenska na tajných mapách 18. storočia. Bratislava: Veda, 2003, s. 36. ISBN 8022406686.

65 Prehl’ad pozri HORVÁTH, Vladimír. Bratislavská pamiatková rezervácia v nákresoch kartografov. In Historické mapy: zborník z vedeckej konferencie 24. - 25. aprila 1997, Bratislava. Ed. Mária Kováčová. Bratislava : Kartografická spoločnost’ SR; Slovenský národný archív, 1997. ISBN 8096697897; KARTOUS, Peter. Bratislavské mestské mapy a plány. In Bratisla$v a$, ročenka, zv. 7, 1971, 183-215; PRIKRYL, L’ubomír Viliam. Vývoj plánov mesta Bratislavy. In Veda a technika $v$ dejinách Slovenska 2. Bratislava: Slovenská spoločnost' pre dejiny vied a techniky pri SAV, 1985, s. 122-141; PURGINA, Ján. Tvorcovia kartografie Slovenska do pol. 18. storočia. Bratislava: Slovenská kartografia, 1972, s. 41-44.

66 AMB, f. Zbierka máp a plánov, inv. č. 31/620.

67 HRNČIAROVÁ, Tatiana. Historický obraz Bratislavy a jej okolia na konci 18. storočia s dôrazom na využitie krajiny. In Geografický časopis, 2016, roč. 68, č. 1, s. 3-24. ISSN 00167193; KUSENDOVÁ, Dagmar. Kartografické diela Jána Mateja Korabinského. In Kartografické listy, 2013, roč. 21, č. 2, s. 24-34. ISSN 1336-5274.

68 Posledný súhrn k historickým plochám zelene: REHÁČKOVÁ, Tamara. Historické záhrady a parky Bratislavy. Bratislava: Trio, 2012. ISBN 9788089552276.

69 Magyar Nemzeti Levéltár Országos Levéltára, Térképtár, f. S 12 Helytartótanácsi térképek, sign. Div. XIV. - No. 23.

70 Ulica sa spomína r. 1775 pod označením Neubau: HORVÁTH, ref. 34, s. 306.

71 O Pálffyho majeri na Blumentáli bližšie: OBUCHOVÁ, Príbehy, ref. 38, s. 208; OBUCHOVÁ, Topografia, ref. 38, s. 24-25.. 
rozparcelovanému záhonu v susedstve križovatky, je zretel'ne vyznačená stavba s dvoma nárožiami patriaca S. Ormosdymu (Ormosdis Gebäude).

Z d’alšej mapovej tvorby treba uviest' plán mesta Bratislavy s blízkym okolím od neznámeho autora, vyhotovený r. $1780 .{ }^{72}$ Zameranie v tomto pláne správne zobrazuje parceláciu a pôdorysné členenie zástavby na predmestí Blumentál. Zakreslený stav na okraji predmestia jasne zachytáva vel'ké rozmery a nepravidelný tvar parcely č. 906. Jej poloha na Mýtnej ulici plne zodpovedá vyššie opísanej situácii. Na pláne je znázornená dvojica pozdížnych budov s nádvorím a v híbke parcely pravidelne upravená záhrada s alejami (francúzsky park). Čiernou ceruzou sú zaznačené rôzne detaily - slávnostná vstupná brána z ulice a ohradenie s vloženou mrežou oddel'ujúce nádvorie od okrasnej záhrady. K majetku prináležiaca nezastavaná plocha (orná pôda) je na severovýchodnej strane ohraničená nepravidelnou líniou, ktorej mierne zalomenia sa dodnes zachovali v priebehu Povrazníckej ulice. Vedl'a rezidencie, smerom von z mesta, je už iba vol'ný priestor bez osídlenia súvislo pokrytý vinohradmi.

Plán s názvom Delineatio geometrica liberae Regiaque Civitatis Posonien$s i s^{73}$ je v dispozícii analogický s predchádzajúcim nákresom, nepodstatné odlišnosti vidno len v stvárnení záhrady, a kresba pôsobí celkovo úhl’adnejším a plastickejším dojmom. Oba plány názorne dokumentujú rozsah Ormosdyho pozemku, ohraničený ulicami Mýtna, Belopotockého, Žilinská a Povraznícka. Posledný relikt pôvodne barokovej záhrady pretrval až do súčasnosti v podobe malého parčíka za budovou Slovenského rozhlasu. ${ }^{74}$

\section{Sídelno-topografická analýza}

Z hl'adiska štruktúry neskorolaténskej sídliskovej aglomerácie leží miesto hromadného nálezu mincí v areáli neopevnenej satelitnej osady, ktorú od podhradia oppida oddel'oval súvislý pás územia bez zástavby, široký cca $400 \mathrm{~m}$. Podl'a súčasného stavu bádania siahal opisovaný sídliskový útvar od Štefanovičovej ul. až po hornú čast' Kollárovho námestia. ${ }^{75} \mathrm{~K}$ spresneniu našich predstáv

72 AMB, f. Zbierka máp a plánov, inv. č. 1023.

73 AMB, f. Zbierka máp a plánov, inv. č. 1024.

74 V prehl’adových prácach registrovaná pod názvom Eszterházyho záhrada na Mýtnej ulici: JANOTA, Dušan - BAGIN, Anton. Historická zeleň Bratislavy. Sady, záhrady a parky. Bratislava: Obzor, 1977, s. 83; REŠOVSKÁ, Zdenka - KLUČÁROVÁ, Zuzana. Revízia a evidencia historických parkov a záhrad na území mesta Bratislavy. Bratislava: ZARES; Mestská správa pamiatkovej starostlivosti a ochrany prírody, 1989, dokument č. 55, rkp., Mestský ústav ochrany pamiatok v Bratislave, oddelenie dokumentácie.

75 VRTEL, Andrej. The internal structure of late La Tène settlement of Bratislava. In Evolution des sociétés gauloises du Second âge du Fer, entre mutations internes et influences externes: Actes du $38^{e}$ collloque de l'AFEAF Amiens 29 mai-1 $1^{\text {er }}$ juin 2014. Eds. Geertrui Blancquaert, 
o rozsahu osídlenia prispeli aj výsledky novších terénnych výskumov na Štefánikovej a Spojnej ulici. ${ }^{76}$

Zaujatie tohto priestoru mohlo sledovat' zámer exploatovania zdrojov kvalitnej hrnčiarskej hliny a zároveň kontroly uzlovej polohy, odkial' viedli tri komunikačné trasy: do sídliskového jadra a k dunajskému brodu; cez priesmyk pod Kalváriou na Pomoravie a po úpätí Malých Karpát smerom na severovýchod. ${ }^{77}$ Pri bližšom pohl'ade na nálezový profil lokality, predovšetkým na skladbu a funkciu odkrytých objektov, sa ukázalo, že osada bola prednostne zameraná na výrobu keramiky. Zretel'ne sa tu črtá sústred'ovanie hrnčiarskych pecí do koncentrovaných zhlukov. ${ }^{78}$

Základný sídliskový obraz dopíňa vyhodnotenie polohy vzhl’adom na ostatné depoty. V bezprostrednom okolí, ako sme už uviedli, sú známe d'alšie tri hromadné nálezy mincí bratislavského typu. ${ }^{79}$

Roku 1927 sa v dolnej časti Námestia slobody ${ }^{80}$ na mieste dnešnej Strojníckej fakulty STU, našiel súbor asi 50 vel'kých a malých strieborných mincí. Pre nedostatok podkladov sa presnú polohu vinohradníckeho domčeka a prehlbovanej pivnice nepodarilo určit'. V. Ondrouch zaznamenal, že nálezcovia vyzdvihli poklad z výplne keltskej chaty. ${ }^{81}$

Ned'aleko odtial' sa r. 1937 pri kopaní kanálu vedúceho ,od ulice Dunstovy k městské plynárně "82 narazilo na 59 vel'kých strieborných mincí, prevažne s ná-

François Malrain. Revue archéologique de Picardie, N Spécial 2016, 30, s. 333-342. ISSN 1272-6117.

76 Nepubl., ústna informácia B. Resutík, Mestský ústav ochrany pamiatok v Bratislave. Citované na základe súhlasu autora.

77 ZACHAR, Lev. Príspevok k problematike bratislavského oppida. In Zborník Slovenského národného múzea, 1982, roč. LXXVI, História 22, s. 39-40, obr. 2.

78 Spôsob rozmiestnenia výrobných objektov na sídliskovej ploche pozri napr.: PIETA, Karol. Wirtschaftliche Strukturen der spätlatènezeitlichen Siedlungen in der Slowakei. In Dürrnberg und Manching. Wirtschaftsarchäologie im ostkeltischen Raum. Akten des Internationalen Kolloquiums in Hallein/Bad Dürrnberg 7. - 11. Oktober 1998. Hrsg. Claus Dobiat, Susanne Sievers, Thomas Stöllner. Bonn: Habelt, 2002, s. 316. ISBN 3774930279; PIETA, Karol ZACHAR, Lev. Mladšia doba železná (laténska). In Najstaršie dejiny Bratislavy. Zost. Tatiana Štefanovičová. Bratislava: Elán, 1993, s. 156-157, 185. ISBN 8085331071.

79 L. Zachar udáva nesprávny počet dvoch depotov: ZACHAR, Príspevok, ref. 77, pozn. 16.

80 Predtým postupne Eszterházyho, Kniežacie, Gottwaldovo nám.; v starších časoch sa používal názov „Fürsten Allee“.

81 ONDROUCH, Nálezy, ref. 14, s. 45, č. 63a. Autor tu odkazuje na vlastný rukopis, ktorého obsah bližšie nepoznáme; text toho času nezvestný, v osobnom fonde Vojtecha Ondroucha v Ústrednom archíve SAV sa nenachádza. V súpisovej časti Ondrouchovej monografie z roku 1958 nie je o depote žiadna zmienka.

82 Dunstová ulica (,Dunstgasse“; ,,Göz utca“), neskôr Starohorská, zanikla pri výstavbe areálu Stavebnej fakulty STU. Z nem. ,, Dunst“, tzn. para, ktorá unikala z plynárne: HORVÁTH, ref. 34, s. 270. Stará plynáreň na Námestí slobody bola v prevádzke v r. 1856 - 1935: OBUCHO- 
pismi BIATEC a NONNOS. Z malej hrncovitej nádobky zdobenej hrebeňovaním, v ktorej boli mince uschované, sa po rozbití zachovala len jej spodná čast'. ${ }^{83}$

Spomenút' však treba najmä depot objavený začiatkom decembra r. 1942 pri výkope základov pre štátny obytný dom na Žilinskej (vtedy Pöllnskej) ulici. ${ }^{84}$ Nález, ktorý odborne vyhodnotil V. Ondrouch, je v súčasnosti najväčším súborom vel'kých strieborných mincí bratislavského typu (spolu 270 razieb) z územia oppida. ${ }^{85} \mathrm{Aj}$ v tomto prípade boli mince údajne uložené v hlinenej nádobe. Podla neoverených správ sa v priestore staveniska vyskytovali zahíbené časti obytných objektov z doby laténskej. ${ }^{86}$

Na bližšiu lokalizáciu sú rôzne názory: Š. Janšák uvádza nárožie Žilinskej a Kopáčskej ul., ${ }^{87}$ iný zdroj polohu v susedstve kina Dukla (YMCA) ${ }^{88}$ Nedostatok spolahlivých priamych dokladov o nálezových okolnostiach preto obrátil našu pozornost' na možnost' spätne zistit' pôvodné nálezisko porovnávaním údajov v spisoch štátnych obytných domov ${ }^{89}$ Zachované situačné nákresy, stavebné plány a úradné povolenia umožňujú označit' ako pravdepodobné miesto nálezu stavbu obytného domu na Žilinskej ul. č. 18 - 20 (r. 1942 - 1947), ${ }^{90}$ s vytýčenou plochou od vyústenia Belopotockého až po Povraznícku ulicu. Vedl’a, smerom

VÁ, Viera. Priemyselná Bratislava. Bratislava: Albert Marenčin - Vydavatel'stvo PT, 2009, s. 107-112. ISBN 9788089218998.

83 ONDROUCH, Vojtech. Nové bratislavské biateky. In Bratislava: časopis pro výzkum Slovenska a Podkarpatské Rusi, 1937, roč. XI, č. 4, s. 355, tab. VI. ONDROUCH, Nálezy, ref. 14 , s. 46, č. 65; FIALA, Anton. Numizmatika. In 140 rokov/Múzeum mesta Bratislavy $1868-2008$. Bratislava: Múzeum mesta Bratislavy, 2008, s. 54. ISBN 9788096986422.

84 Odkúpenie 223 mincí pre Mestské múzeum r. 1943: AMB, f. Magistrát mesta Bratislavy, k. 2607. FAUST, Ovídius - FUZÁK, L’udo. Z histórie Mestského múzea v Bratislave. In 100 rokov Mestského múzea v Bratislave 1868 - 1968. Zost. František Kalesný. Bratislava: Mestské múzeum v Bratislave; Obzor, 1968, s. 25; FIALA, Anton. K hromadným nálezom mincí v Múzeu mesta Bratislavy. In Kelti z Bratislavy. Bratislava: Slovenské národné múzeum-Historické múzeum; Mestský ústav ochrany pamiatok, 2016, s. 142. ISBN 9788097236601.

85 ONDROUCH, Vojtech. Nový typ mince ze skupiny Biateků. In Archeologické rozhledy, 1951, roč. III, s. 318. ISSN 0323-1267; ONDROUCH, Keltské mince, ref. 7, s. 13; ONDROUCH, Nálezy, ref. 14, s. 46, č. 66.

86 ONDROUCH, Keltské mince, ref. 7, s. 14.

87 JANŠÁK, Hrnčiarska dielňa, ref. 10, s. 195, obr. 1; DEKAN, Ján. Rozvoj keltského osídlenia a Rimania. In Dejiny Bratislavy. Zost. Darina Lehotská, Ján Pleva. Bratislava: Obzor, 1966, s. 25 .

88 POLLA - VALLAŠEK, ref. 15, s. 178, obr. 157.

89 AMB, f. Útvar hlavného architekta mesta Bratislavy (1849 - 1967), Žilinská ulica.

90 Celý názov: Novostavba štátneho obytného domu pre zamestnancov rezortu verejných prác, Pöllnská ul. č. 16 - 18, parc. č. 7866/1 - 2, č. p. V. 97. Ministerstvo vnútra Slovenskej republiky, Štátny oblastný archív v Bratislave, f. Daňová správa Bratislava - mesto, k. 235, Žilinská cesta $16-18$. 
k Šancovej ulici, sa nachádzal areál bývalej Menzlovej továrne na asfalt, lepenku, strešné krytiny a izolačné látky. ${ }^{91}$

Pripomeňme ešte jednu súvislost', a to predpoklad roztrateného nálezového celku na bližšie neznámom mieste v Bratislave z r. 1938, ktorý vyslovil J. Militký. ${ }^{22} \mathrm{Na}$ druhej strane sa nedá úplne vylúčit', že ide o súčast' iného, už evidovaného depotu (napr. z r. 1937). Do úvahy prichádza aj menej pravdepodobná možnost' ojedinelého nálezu stratovej mince.

Pochybnosti o spol’ahlivosti lokalizovania sa prirodzene vynárajú pri viacerých starších archeologických objavoch v oblasti Bratislavy, no nie je možné zaoberat' sa na tomto mieste všetkými (napr. s odstupom času už t'ažko overit' správnost' polohy hromadného nálezu keltských mincí „, z l'avobrežnej strany Dunaja, z bratislavskej župy, asi z roku 1910“).93

Poznatky o charaktere osídlenia a význame jednotlivých zložiek bratislavskej aglomerácie doplńa hodnotenie geografického rozmiestnenia mincových depotov. Výsledok sledovania ich distribúcie ukazuje, že väčšina nálezísk sa viaže na okrajové časti sídliska. ${ }^{94}$ Výrazné zoskupenie štyroch hromadných nálezov mincí sa zaznamenáva v satelitnej osade v okolí Námestia slobody a d’alší súbor na východnom okraji podhradia. ${ }^{95} \mathrm{Z}$ opevnenej akropoly oppida pochádzajú dva výnimočné poklady keltských mincí.

Pri kritickom pohl'ade na nedostatočný stav terénneho bádania v periférnom pásme neskorolaténskej aglomerácie môžeme poukázat' na zaujímavý paradox: v satelitnej zóne počet mincových depotov nápadne prevyšuje kategóriu ojedinelých nálezov stratových mincí (evidované jedno nálezisko - Šancová ul.,YMCA, okolo r. 1942)..$^{96}$

91 OBUCHOVÁ, Priemyselná Bratislava, ref. 82, s. 204.

92 MILITKÝ, Jiř́. Zapomenutý nález keltské mince typu AINORIX z Bratislavy. In Slovenská numizmatika, 2004, roč. XVII, s. 189-190. ISBN 8088709768; SCHULZ, Eug. O bójské minci Ainorixově. Addendum k Paulsenovi. In Numismatické zprávy. Časopis pro sběratele mincí a medailí, 1940, roč. 7, s. 9-13.

93 KOLNÍKOVÁ, Eva. Neznámy hromadný nález keltských mincí z okolia Modry alebo Jura pri Bratislave z roku 1910. In Slovenská numizmatika, 1990, roč. XI, s. 249-253. ISBN 8022401803.

94 Porov.: NOVOTNÝ, Bohuslav. Bratislava praveká (minulost’ územia Bratislavy od najstarších čias po zmenu letopočtu). In Najstaršie dejiny Bratislavy : referáty zo sympózia 28. 30. októbra 1986. Zost. Vladimír Horváth. Bratislava: Bratislavská informačná a propagačná služba; Archív hlavného mesta SSR Bratislavy, 1987, s. 43.

95 Prehl'ad prípadov sústredenia depotov na úzkom priestore pozri: KURZ, Gabriele. Keltische Hort- und Gewässerfunde in Mitteleuropa - Deponierungen der Latènezeit. Stuttgart: Theiss, 1995, s. 109. ISBN 3806212228.

96 Pozri: HLINKA, Jozef - KOLNÍKOVÁ, Eva - KRASKOVSKÁ, L’udmila - NOVÁK, Jozef. Nálezy mincí na Slovensku III. Bratislava: Veda, Vydavatel'stvo Slovenskej akadémie vied, 


\section{Závery a diskusia}

Hl'adanie odpovede na základnú otázku, kde presne sa na území Bratislavy r. 1776 našiel tzv. prvý poklad biatekov, viedlo k viacerým prekvapivým zisteniam.

V prvom rade sa preukázalo, že miesto nálezu ležalo na severnom okraji predmestia Blumentál - v dnešnom bloku, ktorý zvierajú ulice Mýtna, Belopotockého, Žilinská a Povraznícka. Navrhovaná lokalizácia súhlasí s opisom náleziska v správe K. G. Windischa a plne zodpovedá stavu pozemkového majetku S. Ormosdyho v danom roku. Nové polohové určenie sa opiera o miestopisné práce, mestské úradné knihy, cirkevné matriky a jeho správnost' potvrdzujú napokon i mapové diela.

Z čiastočnej revízie nálezových okolností pokladov keltských mincí z oblasti Námestia slobody vyplýva, že miesta ukrytia (vyzdvihnutia) depotov z r. 1776 a 1942 sa v podstate zhodujú - ide o ten istý pozemok patriaci pôvodne S. Ormosdymu.

Situovanie náleziska do tohto priestoru sa zdá byt' opodstatnené i z hl'adiska archeologickej topografie, pretože vel'mi dobre zapadá do predstáv o rozsahu tzv. satelitnej osady keltského oppida. V súčasnosti ide o zónu s najvyššou koncentráciou hromadných nálezov keltských mincí bratislavského typu (spolu štyri). Táto vysoká početnost' depotov môže priamo súvisiet's výhodnou komunikačnou polohou osady. Rozdiel v zastúpení hromadných nálezov je obzvlášt' markantný pri porovnaní s územím východného podhradia (jeden súbor mincí). Pravda, pri hodnotení tohto nepomeru treba vziat' do úvahy i odlišnú históriu stavebnej činnosti v oboch častiach mesta. Druhé výraznejšie zoskupenie mincových depotov sa rysuje $\mathrm{v}$ okruhu akropoly, kde sa okrem iného vyskytli dva komplexy s odlišnou obsahovou štruktúrou (Hrad, r. 1965: razby cudzej proveniencie - norické; Zimná jazdiareň, r. 2009: strieborné a naviac i zlaté mince bratislavského typu). ${ }^{97}$

Okruh problémov spojených s témou deponovania v neskorej dobe laténskej na území Bratislavy je značne široký, po načrtnutí priestorových súvislostí sa pokúsime aspoň krátko osvetlit' niektoré d'alšie podstatné znaky - vel'kost' a skladbu súborov, druh obalu.

Čo sa týka počtu razieb v hromadných nálezoch, vierohodnost' údajov je podmienená najmä spôsobom nadobudnutia: až na jednu výnimku boli totiž všetky depoty mincí bratislavského typu objavené pred r. 1945 náhodne, t. j. mimo rámca archeologických výskumov. V posudzovanom korpuse nechýba ani kategória

1978, s. 13.

97 KOLNÍKOVÁ, Eva. Norische Münzen im Oppidum Bratislava und in seinem Hinterland. In Slovenská numizmatika, 1996, roč. XIV, s. 9-57. ISBN 8090115934; MUSILOVÁ - KOLNÍKOVÁ - HLOŽEK, ref. 16, s. 239-308. 
úplne roztratených pokladov. ${ }^{98} \mathrm{~V}$ prípade súboru zo štvrte Hausbergeln (severozápadné podhradie oppida) je dokonca t’ažké zodpovedne rozhodnút', či pochádza z jedného alebo z dvoch samostatných depotov. ${ }^{99}$

Pri známom alebo približne odhadovanom celkovom počte mincí prichádzame k záveru, že z prostredia satelitnej osady sú k dispozícii tri rôzne vel'kostné a kombinačné skupiny depotov, a to s obsahom:

a. spolu cca 50 vel'kých a malých strieborných mincí;

b. cca 50 hexadrachiem;

c. 270 hexadrachiem (vel'ký poklad). ${ }^{100}$

Spoločným znakom troch hromadných nálezov keltských mincí na periférii osídlenia, konkrétne v polohách Ormosdyho pozemok (r. 1776), Nám. slobody (r. 1937) a Žilinská ulica (r. 1942), je ukrytie v hlinenej nádobe. ${ }^{101} \mathrm{O}$ schránke d’alšieho pokladu z Nám. slobody (r. 1927) nie sú žiadne záznamy. Zvláštny prípad tvoria pozostatky dislokovaných depotov, ktorých primárny spôsob uloženia sa už nedá spätne rekonštruovat'. Takéto situácie s vol’ne rozptýlenými (druhotne roznesenými) mincami boli odkryté na hornej východnej terase hradného $v r c h u^{102}$ a v priestore Zimnej jazdiarne. ${ }^{103}$ Zo súboru porušeného pri zakladaní

98 Hromadný nález objavený r. 1927 na Námestí slobody. Podla V. Ondroucha uchovával šest' razieb v súkromnej zbierke Karol Junek z Bratislavy. ONDROUCH, Nálezy, ref. 14, s. 45, č. 63a. Pozri pozn. č. 82 .

99 V súpisových katalógoch sa obvykle uvádzajú dva poklady: KOLNÍKOVÁ, ref. 8, príloha 1, s. 61; ONDROUCH, Keltské mince, ref. 7, s. 99-100; ONDROUCH, Nálezy, ref. 14, s. 45-46, č. 62,64 .

100 Najčastejší počet predstavuje niekol'ko desiatok razieb: PIETA, Karol. Keltské osídlenie Slovenska. Mladšia doba laténska. Nitra: Archeologický ústav SAV, 2008, s. 208. ISBN 9788089315055. Otázka hodnoty ako rozlišovací znak motivácie ukrývania: ZIEGAUS, Bernward. New Aspects on Celtic Coin Hoards in Southern Germany. In Prehistoric Gold in Europe. Mines, Metallurgy and Manufacture. Eds. Giulio Morteani, Jeremy P. Northover. Boston: Kluwer Academic Publishers, 1995, s. 597-608. ISBN 0792332555.

101 ONDROUCH, Nové bratislavské, ref. 83, s. 355, tab. VI. Totožným spôsobom bol uschovaný súbor mincí v Deutsch Jahrndorfe (r. 1855): KUPIDO, F. S. Die Silbermünzen des Jarendorfer Fundes. In Wiener Numismatische Monatshefte, 1866, II. Band, s. 98-106; RUSKE, Alexander. Die Fundregesten der antiken Münzhorte aus Österreich. Eine Zusammenstellung aller bekannten Münzdepots anhand der Literatur. In Festschrift für Günther Dembski zum 65. Geburtstag, Teil II. Hrsg. Heinz Winter. Numismatische Zeitschrift, 2011, Band 118, s. 62. ISSN 0250-7838.

102 ČAMBAL, Radoslav. Bratislavský hradný vrch - akropola neskorolaténskeho oppida. Bratislava: Slovenské národné múzeum, 2004, s. 42. ISBN 8080601410; HOLČÍK, Štefan. Klenoty dávnej minulosti Slovenska. Bratislava: Slovenské národné múzeum; Martin: Osveta, 1988, s. 50; KOLNÍKOVÁ, ref. 97, s. 10; ŠTEFANOVIČOVÁ, Tatiana. Bratislavský hrad v 9. - 12. storočí. Bratislava: Obzor, 1975, s. 13.

103 MUSILOVÁ - KOLNÍKOVÁ - HLOŽEK, ref. 16, najmä s. 247, 250; VRTEL, Andrej. Bemerkungen zum Katastrophenhorizont des Bratislavaer Oppidums. In Waffen - Gewalt- 
budovy na Námestí republiky sa podarilo zozbieraním na ploche $1-2 \mathrm{~m}^{2}$ zachránit' 76 vel'kých a 324 malých strieborných mincí, ostatné unikli pozornosti nálezcov a vyviezli ich spolu so stavebnou sutinou do Dunaja. ${ }^{104} \mathrm{~J}$. Eisner sa domnieval, že pôvodne mohli byt' uschované v koženom vaku alebo truhlici. ${ }^{105}$

S nálezovými okolnost’ami väčšiny starších objavov sa pre nedostatky sprievodnej dokumentácie spája vel'a nejasností a pochybností, napr. v otázke výskytu v sídliskových objektoch a vrstvách. Torzovitý stav zachovania neumožňuje posúdenie numizmatických aspektov (stupeň opotrebovania mincí, kvalita mincového kovu, úroveň razby, typologická variabilita, väzba razidiel a pod.) a výrazne tak znižuje výpovednú hodnotu nálezov. ${ }^{106}$

Predložená štúdia je čiastkovým pokusom o objasnenie topografického kontextu vybraných nálezových celkov. Pri interpretovaní fenoménu deponovania v závere keltského osídlenia v Devínskej bráne treba vychádzat' zo širšej perspektívy a zvolit' taký prístup k téme, ktorý by súčasne kriticky zhodnotil aj hromadné nálezy železných predmetov (Gottwaldovo nám., objekt 1/52; Radničná ul. 1, objekt 33/06). ${ }^{107}$

* Štúdia bola vypracovaná v rámci projektu VEGA č. 1/0762/14 Keltské hrnčiarstvo na strednom Dunaji. Hrnčiarske dielne a vypal'ovacie zariadenia z neskorej doby laténskej od Devinskej brány po ohyb Dunaja.

Krieg. Beiträge zur Internationalen Tagung der AG Eisenzeit und des Instytut Archeologii Uniwersytetu Rzeszowskiego, Rzeszów 19. - 22. September 2012. Hrsg. Stefanie Wefers, Maciej Karwowski, Janine Fries-Knoblach, Peter Trebsche, Peter C. Ramsl. Langenweißbach: Beier \& Beran, 2015, s. 58, 63. ISBN 9783957410429.

104 ONDROUCH, Vojtěch. Z novějších nálezů barbarských a římských mincí na Slovensku. In Sbornik Matice slovenskej, 1935, roč. XIII, č. 4, s. 322, 324; ONDROUCH, Nové bratislavské, ref. 83, pozn. 5 .

105 EISNER, Jan. Mince typu Biatec, nalezené v Bratislavě r. 1923. In Numismatický časopis československý, 1925, roč. I, s. 87-88.

106 NEMEŠKALOVÁ-JIROUDKOVÁ, Zdenka. K pracovním metodám v keltské numizmatice. In Slovenská numizmatika, 1982, roč. VII, s. 79-87; RUSKE, Alexander. Der Zyklus eines Hortfundes: methodische Überlegungen zur Bildung, Deponierung, Zusammensetzung und Bergung von Münzhorten anhand des Beispiels der antiken österreichischen Schatzfunde. In Numismatický sbornik, 2009, roč. 24, s. 65-94. ISBN 9788070073384.

107 KRASKOVSKÁ, L’udmila. Nález železných nástrojov v hrnčiarskej peci v Bratislave. In Archeologické rozhledy, 1962, roč. XIV, č. 3, s. 340-343, 370. ISSN 0323-1267; PAULÍK, Jozef. Najstaršie hromadné nálezy železných predmetov na Slovensku. In Zborník Slovenského národného múzea, 1970, roč. 64, História 10, s. 48, obr. 15; VRTEL, Andrej. Neskorolaténske oppidum v Bratislave - remeselná výroba, výmena a obchod. Nepubl. dizertačná práca. Nitra: Archeologický ústav SAV, 2009, s. 73, tab. 9. 
EIN IM JAHRE 1776 ENTDECKTER KELTISCHER MÜNZSCHATZ AUS BRATISLAVA

LOKALISIERUNG DER FUNDSTELLE

\section{ANDREJ V R T E L - ROBERT GREGOR M A R E T T A}

Das Objekt der Studie ist eine genauere Bestimmung des Ortes, wo im J. 1776 die Finder einen Schatz von 44 großen Silbermünzen mit Inschriften BIATEC, NONNOS, COBROVOMARVS und FAPIARIX geborgen haben. Die Ansichten, die den Hortfund von keltischen Münzen auf das rechte Donauufer oder in den historischen Stadtkern lokalisieren, lehnen wir als unbegründet ab. Die Primärquellen (J. H. Eckhel, K. G. von Windisch) in Bezug auf die Fundumstände führen ausdrücklich eine Lage in der äußeren Vorstadt von Bratislava und auf einem Grundstück von S. Ormosdy an; aus zeitgenössischen Berichten ergibt sich auch die Annahme einer geringen Entfernung von der Landstraße. Die Bestimmung der genauen Fundstelle hängt von einer detaillierten Rekonstruktion der Entwicklung der Vermögensverhältnisse von S. Ormosdy ab. Wir verwerten dabei topographische Quellen (J. M. Korabinský), Stadtbücher, Kirchenbücher (Pfarrbezirke Blumenthal, St. Martinsdom und Podunajské Biskupice) und kartographische Denkmäler (Stadtkarten und -pläne). Die Ergebnisse der Archivforschung verweisen klar und deutlich auf Ormosdys Grundstücke am nördlichen Rand der Blumenthaler Vorstadt, in einem Bereich, der heutzutage von den Straßen Belopotockého, Mýtna, Povraznícka und Žilinská begrenzt ist. Die obengenannte Lage gehört zum Gebiet der sog. Satellitensiedlung des keltischen Oppidums in Bratislava. Vom Areal der Siedlung, die sich in breiterer Umgebung des Platzes Námestie slobody erstreckte, kennen wir noch drei weitere Horte von keltischen Münzen des Bratislavaer Typus. Die Überprüfung ihrer Fundumstände deutet an, dass der große Depotfund aus dem J. 1942 (Aufbau von staatlichen Wohnhäusern, Žilinská-Straße) höchstwahrscheinlich auf demselben, ursprünglich Ormosdys Grundstück entdeckt wurde. Die neuen Feststellungen werfen die Frage der Interpretation einer solch deutlichen Konzentration der Münzhorte in diesem peripheren Teil der spätlatènezeitlichen Siedlungsagglomeration auf.

Mgr. Andrej Vrtel, PhD.

Univerzita Komenského v Bratislave

Filozofická fakulta

Gondova 2

81499 Bratislava

e-mail: andrej.vrtel@uniba.sk

Mgr. Robert Gregor Maretta

Archív Slovenského národného múzea

Žižkova ul. 18

81006 Bratislava

e-mail: robert.maretta@snm.sk 


\section{DANA DUCHONOUA TUNDE L ENGYELOVA}

Hradné kuchyne

a šlachtické stravovanie

v ranom novoveku

\section{Radosti slávností, strasti každodennosti}

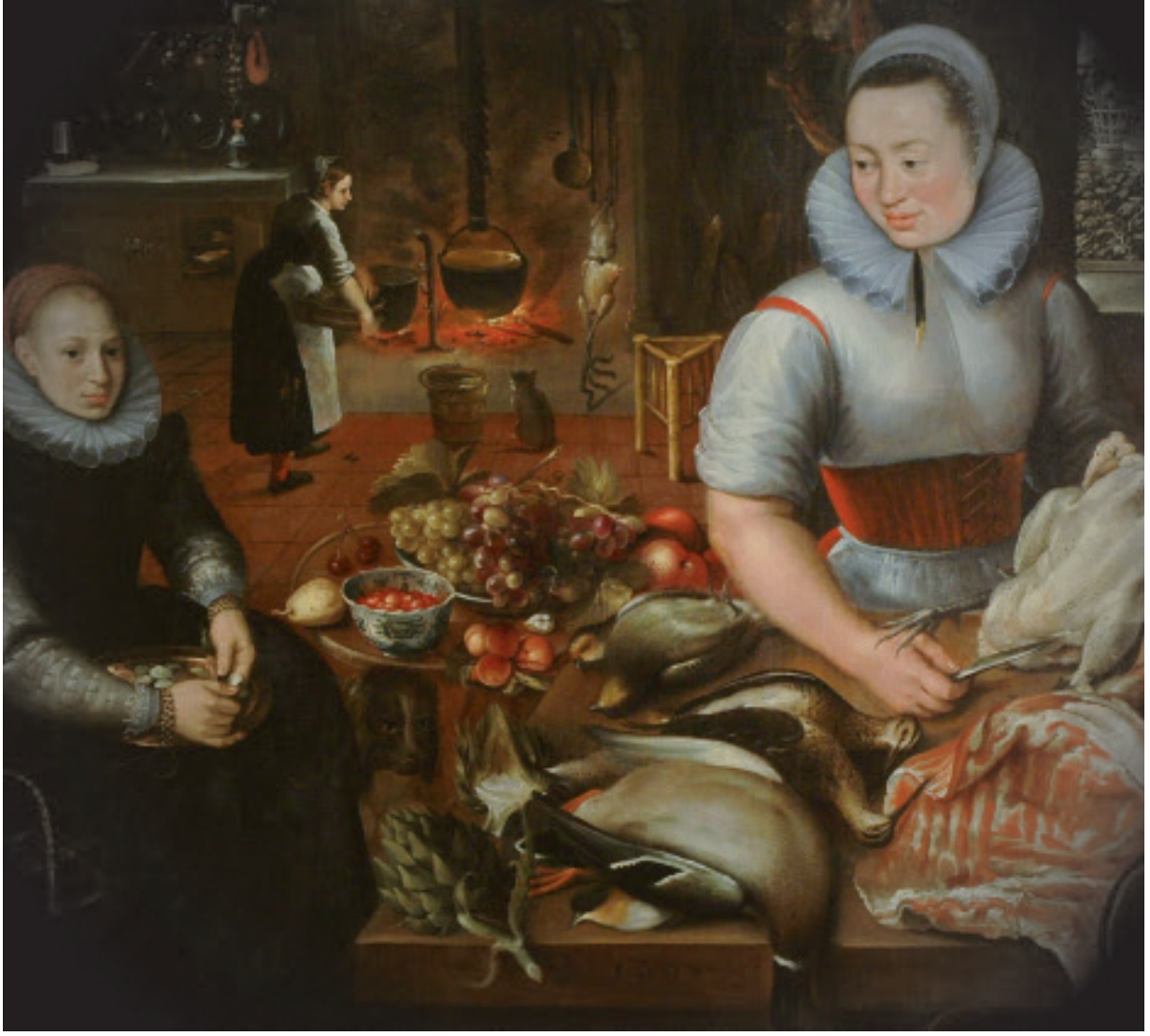

